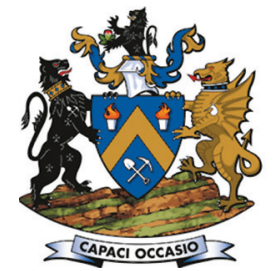

Affiliation:

${ }^{1}$ GCS (Pty) Ltd, South Africa.

Correspondence to:

A.C. Johnstone

Email:

andrewj@gcs-sa.biz

Dates:

Received: 1 Mar. 2021

Revised: 4 Jun. 2021

Accepted: 5 Jun. 2021

Published: October 2021

\section{How to cite:}

Johnstone, A.C. 2021

Are pit lakes an environmentally sustainable closure option for opencast coal mines? Journal of the Southern African Institute of Mining and Metallurgy, vol. 121 , no. 10, pp. 531-536

\section{DOI ID:}

http://dx.doi.org/10.17159/24119717/1551/2021

This paper was first presented at the Mine-Impacted Water from Waste to Resource Online Conference, 10 and 12,17 and 19 , 3 and 24 November 2020

\title{
Are pit lakes an environmentally sustainable closure option for opencast coal mines?
}

\author{
A.C. Johnstone
}

\begin{abstract}
Synopsis
The aim of the study is to determine if pit lakes are a sustainable coal mine closure option in South African. The water balance, chemistry, limnology, and bacterial population of three selected pit lakes were investigated. The lakes are in the three major coal basins of South Africa and are associated with different lithologies and mining methods. The major factors driving the water balance of the pit lakes are direct rainfall, runoff, inflow from old mine workings, and groundwater infiltration, with the major losses being evaporation or discharge onto surface. The study indicated that pit lakes can be designed as 'terminal sinks' to provide a sustainable mine closure option. The pit lakes sampled have an alkaline $\mathrm{pH}$, and mostly a sodium/calcium sulphate water with total dissolved solids content of less than $3000 \mathrm{mg} / \mathrm{l}$. The phytoplankton and microbiological data indicates that the pit lakes support aquatic life. The study shows that correctly designed pit lakes can be an environmentally sustainable closure option for South Africa's coal mines. A suggested design manual has been developed to assist mine owners and regulators in developing sustainable coal mine pit lakes as a closure option.
\end{abstract}

\section{Keywords}

coal mine. pit lakes, water quality, water balance, mine closure.

\section{Introduction}

Coal mining started in South Africa in the early 1800s, initially by conventional underground methods, but since the 1950s the majority of the coal production has been from opencast operations. Coal supplies $95 \%$ of South Africa's power needs and will probably continue to do so through the first half of the 21st century. In addition, South African coal production for export and domestic non-power generating purposes is estimated to be $150 \mathrm{Mt} / \mathrm{a}$.

Opencast coal mines generally leave a final void due to the mining method, or insufficient overburden to fill the void left by mining, or as a water management strategy. When the mining operations cease, the void fills with water and forms a lake, which is generally referred to as a 'pit lake'. The author estimates that there are over 120 pit lakes in the three major coalfields, namely the Witbank, KwaZulu-Natal, and Waterberg coalfields. This study evaluates the environmental sustainability of using pit lakes as a closure option for coal mines in South Africa. The current South African mining and environmental legislation states that in order for a mine to achieve closure, all pit lakes should be backfilled. ${ }^{1}$

The major factors that determine the environmental sustainability of a pit lake are the water balance and quality. A positive water balance results in discharge from the pit lake onto the surface. A further consideration for environmental sustainability is the chemical and biological nature of the water. Pit lake water quality varies depending on the geology, mining method, and catchment characteristics. In general, pit lake water quality may not comply with legislated catchment water quality standards. This investigation considered three pit lakes with the focus on the two major drivers of pit lake sustainability, namely water quality and water balance.

The pit lakes studied were selected on the basis that they are representative of the three major South African coalfields, considering differences in geology and climatic conditions. The factors affecting pit 


\section{Are pit lakes an environmentally sustainable closure option for opencast coal mines?}

lake water balance (and as a result the variation in water level) are groundwater, direct rainfall, and runoff, while the losses from the pit lakes are evaporation, surface discharge, and flow into the surrounding aquifers. The water balance of each of the pit lakes was evaluated to determine the major inputs and losses. The major inputs were identified as groundwater from either the aquifer or backfilled material, and the major loss was evaporation. Pit lake morphology, volume, and surface area are the major design considerations to prevent discharge of lake water into the catchment.

The chemical and biological evolution of the water quality determines the long-term ecological sustainability of pit lakes. The inorganic chemistry study concentrated on the water quality and vertical stratification. The vertical variation in $\mathrm{pH}$, temperature, dissolved oxygen, and redox potential was measure on a systematic basis in each of the pit lakes. The biotic study investigated the phytoplankton, chlorophyll-a, and the microbiology of each of the lakes.

The waters in the pit lakes are alkaline and have elevated total dissolved solids (mainly calcium sulphate) compared to the ambient surface and groundwater. The pit lakes support life in the form of chlorophyll-a, phytoplankton, microorganisms (bacteria), vegetation, and aquatic life.

A fundamental change in thinking and legislation is required for pit lakes to be accepted as an environmentally sustainable closure option for South African coal mines. This will prevent uncontrolled discharge from opencast mining operations and avoid the expense of ongoing water treatment and associated impacts. Correctly designed pit lakes offer an environmentally sustainable closure option for opencast coal mines in South Africa. Sufficient data was collected in the study to develop a guideline for the design of coal mine pit lakes in the Southern African coalfields. The manual considered the water balance of the pit lakes and the biological and chemical processes that drive the water quality.

\section{Pit lake water balance}

Pit lake water balances in South Africa are largely controlled by evaporation, as evaporation exceeds precipitation by a factor of 2 to 3 . As a result, if the inflow into a pit lake is managed it is unlikely that it will discharge onto surface and into the catchment. The water balances of the pit lakes were calculated based on a generalized mathematical expression (after Gammons et al., 2009):

$$
\Delta S=(P+S W \text { in }+G W \text { in })-(E+(T)+S W \text { out }+G \text { Wout })
$$

where

$\Delta S \quad$ is change in storage, which is the volume of water in the lake

$P \quad$ is the precipitation falling onto the pit lake

$S W$ in is the sum of any surface water inputs, which includes runoff and diverted streams

GWin is groundwater entering the lake

$E \quad$ is the evaporation from the lake

$T \quad$ is plant transpiration, which is often negligible

$S W$ out is surface water leaving the pit lake, and includes pumpage

$G \quad$ Wout is the groundwater leaving the pit lake

$S W$ in can be managed by minimizing runoff into the pit lake. GWin can be minimized (by allowing groundwater levels to rebound) so that evaporation will exceed the sum off all inflows into the pit lake and the lake will act as a water sink.

\section{Pit lake water quality}

A major consideration is the final pit lake water quality on closure of a mine. This affects the environmental classification and as a result the environmental sustainability of the lake. Conceptual models of pit lake geochemistry are described by external and internal processes, with many of the internal processes being mediated by algae and microbes (Gammons et al., 2009).

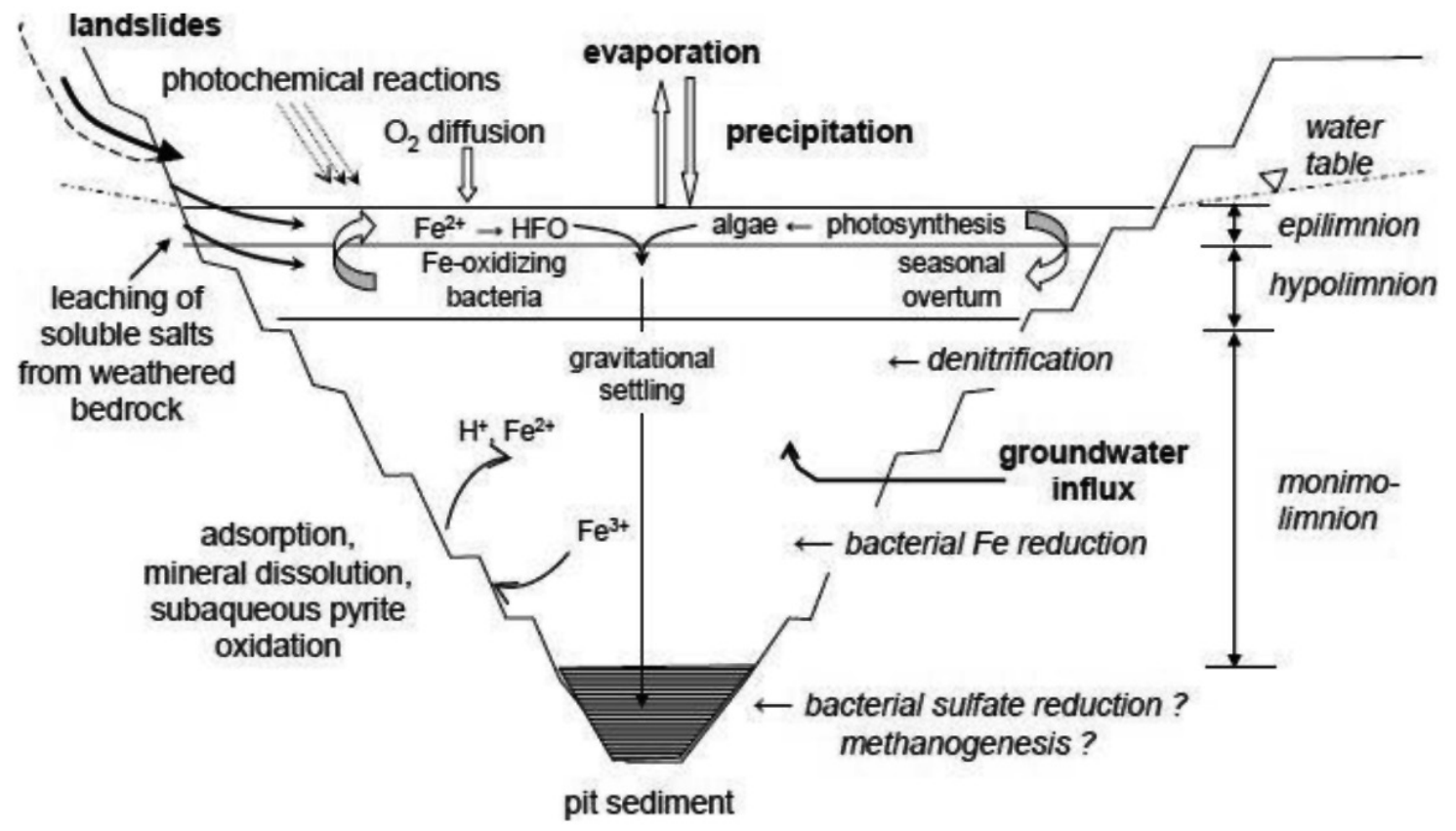

Figure 1-Chemical processes in pit lakes (Gammons et al., 2009) 


\section{Are pit lakes an environmentally sustainable closure option for opencast coal mines?}

External processes comprise wallrock runoff and inflow from groundwater, and flow from surface and subsurface mine waste facilities. The quality of the inflows into the pit lake also impacts the evolution of the water quality. Figure 1 summarizes the chemical processes that determine the pit lake water quality.

\section{The evolution of a pit lake at a South African coal mine}

After mining ceases, water levels in the pit lake rebound to approximately pre-mining groundwater levels. The inflows into the pit lake are rainfall, groundwater, and surface runoff. As water levels rebound the relative contribution of groundwater to the overall pit lake water balance decreases. Rebounding groundwater enters the pit via the dewatered aquifer and from mining activities. The groundwater transports the products of pyrite oxidation, mainly sulphate, iron, and acidity, and dissolves secondary minerals that might have formed in the dewatered aquifer or the backfill material.

\section{Pit lake morphology}

The pit shape is important from a water balance and quality point of view for the following reasons.

> Large surface area compared to mean depth, linear/ elongated pit lake morphology. These pit lakes are more prone to the effects of evaporation and evapoconcentration. Larger surface areas increase losses by evaporation, with lower potential for discharge/overflow, and ensure a groundwater gradient towards the pit lake, to act as a hydrological sink.

> Small surface area to mean depth ratio or cone-shaped pit lakes. These pit lakes tend to form an isolated bottom layer, called the monimolimnion, with inferior water quality compared to the rest of the lake. If the chemistry and physical structure of the pit lake are stable, the isolated layer may be beneficial for detaining heavy metals. Conversely, an isolated layer may not be desirable, as sudden storms events may disturb the chemocline and cause this layer to turn over and mix poor, metal-rich water through the whole water column with deleterious effects on the overall water quality.
Thus, pit lakes with high depth to width ratios are less susceptible to complete lake turnover (Gammons et al., 2009). Therefore, the relative depth is a good measure for the shape of the pit lake basin (Schultze, 2012). The relative depth is also referred to as the 'aspect ratio' and can be described as a comparison of the maximum depth $\left(Z_{\max } ; \mathrm{m}\right)$ of the lake to the lake surface area (Asurface; $\mathrm{m}^{2}$ ). The relative depth is expressed as a percentage (Castendyk, Eary, and Balistrieri, 2015; Vandenberg, Mccullough, and Castendyk, 2015). The calculation of relative depth is shown in Equation [1]:

$$
Z_{\text {relative (\%) }}=\frac{50 \times z_{\max } \times \sqrt{\pi}}{A_{\text {surface }}}
$$

\section{Case studies}

Three case studies, namely the pit lakes at Mafuta, Kriel, and Rooikop, were undertaken. The characteristics of the pit lakes are shown in Tables I and II.

Mafutha is single open pit $90 \mathrm{~m}$ deep from which 250 $000 \mathrm{t}$ of material were removed. The pit is surrounded by an undisturbed aquifer and surface runoff into the pit is largely from the sidewalls. The pit lake has reached equilibrium where groundwater inflow plus direct rainfall equals evaporation, thus resulting in very minor variations in pit lake water levels. The pit lake water at Mafutha is alkaline with a TDS of $1000 \mathrm{mg} / \mathrm{l}$ and a sodium chloride type water.

The Kriel site comprises several hydraulically linked open pits left by the extensive opencast mining operations. The pit lakes are hydraulically connected due to the highly permeable backfilled opencast material between the lakes. In this system the major inflows are direct rainfall, runoff, and significantly greater recharge through the overburden spoils. Inflow exceeds evaporation and groundwater outflow, resulting in periodic outflow onto the surface. The pit lake water is alkaline with a TDS of $3500 \mathrm{mg} / \mathrm{l}$ and is largely a sodium calcium sulphate water.

The Rooikop pit lake is hydraulically connected to both underground and opencast mine workings. Inflow is from groundwater recharge to the underground workings from the opencast spoils and surface runoff. The pit lake is alkaline with

\section{Natural Lake Morphology: \\ Surface Area $=100,000 \mathrm{~m}^{2}$ \\ Maximum Depth $=5 \mathrm{~m}$ \\ Relative Depth $=1.4 \%$ \\ No Wind Sheltering}

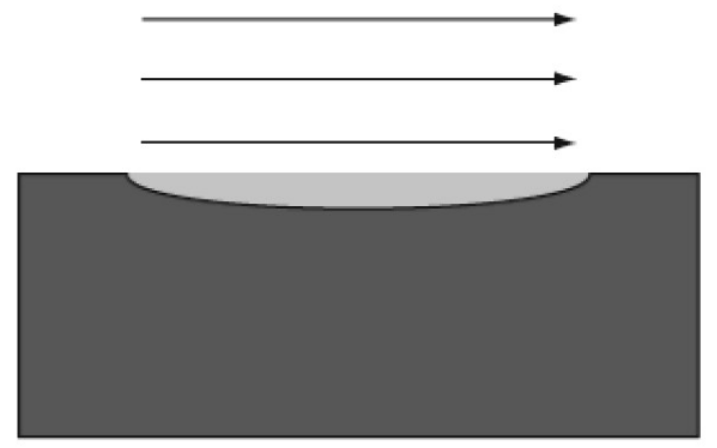

Pit Lake Morphology:

Surface Area $=100,000 \mathrm{~m}^{2}$

Maximum Depth $=100 \mathrm{~m}$

Relative Depth $=\mathbf{2 8 . 0 \%}$

Walls Shelter Surface from Wind

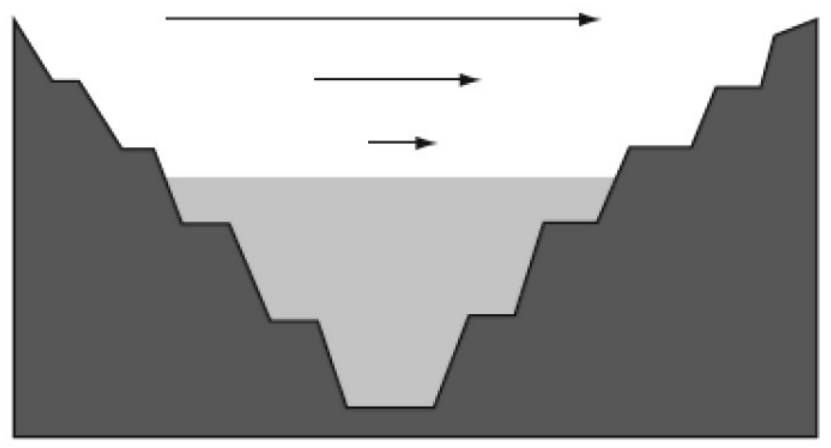




\section{Are pit lakes an environmentally sustainable closure option for opencast coal mines?}

Table I

Pit lake physical characteristics

\begin{tabular}{|l|c|c|c|}
\hline & Mafutha & Kriel & Rooikop \\
\hline Coalfield & Waterberg & Multiple pits hydraulically connected & Single lake \\
\hline Nature of pit lake & Deep single open pit & Opencast rollover method & Opencast and underground \\
\hline Mining method & Bulk sample & Operational to 13 years old & 12 \\
\hline Age (years) & 8 & 272530 & 17100 \\
\hline Surface area (m) & 26600 & 797071 & Underground mine workings, Runoff from backfill, and natural topography \\
\hline Volume (m) & 505800 & Groundwater, rainfall. runoff & Discharge, evaporation \\
\hline Dominant inflows & Groundwater, rainfall & Evaporation & 6.8 \\
\hline Dominant outflows & Evaporation & 3,2 & 10 \\
\hline Morphology (\%) & 38.4 & $7-10$ & \\
\hline Depth $(m)$ & 70 & & \\
\hline
\end{tabular}

\section{Table II}

Comparison of pit lake chemistry, phytoplankton, and microbiology measured during the 2016-2017 study period

\begin{tabular}{|c|c|c|c|}
\hline Pit lake & Mafutha & Kriel & Rooikop \\
\hline $\mathrm{pH}$ & & 8.4 & 8.47 .9 \\
\hline Temperature $\left({ }^{\circ} \mathrm{C}\right)$ & $\begin{array}{l}27.2 \text { (epilimnion, summer) } \\
18.6 \text { (hypolimnion, summer) } \\
18.6 \text { (whole pit lake, winter) }\end{array}$ & $\begin{array}{l}20.6 \text { (summer) } \\
13.5 \text { (winter) }\end{array}$ & $\begin{array}{l}20 \text { (summer) } \\
15.3 \text { (winter) }\end{array}$ \\
\hline Dissolved oxygen (mg/l) & $\begin{array}{l}7.53 \text { (epilimnion, summer) } \\
1.3 \text { (hypolimnion, summer) } \\
6.95 \text { (whole pit lake, winter) }\end{array}$ & $\begin{array}{l}\text { R44: } 2.03 \text { (summer), } 5.7 \text { (winter) } \\
\text { R42: } 4.9 \text { (summer), } 8 \text { (winter) }\end{array}$ & $\begin{array}{l}8.3 \text { (summer) } \\
7.9 \text { (winter) }\end{array}$ \\
\hline TDS (mg/l) & 1000 & 3443 & 1208 \\
\hline Total hardness (as mg/l CaCO${ }_{3}$ ) & 186 & 1210 & 712 \\
\hline Sodium (mg/l) & 301 & 434 & 18 \\
\hline Total alkalinity (mg/l) & 326 & 197 & 118 \\
\hline Sulphate (mg/l) & 94 & 1930 & 608 \\
\hline Chloride (mg/l) & 314 & 35 & 2.5 \\
\hline Nitrate- $\mathrm{NO}_{3}(\mathrm{mg} / \mathrm{l})$ & 9.7 & 0.24 & $<0.1$ \\
\hline Water type & $\mathrm{Na}-\mathrm{Cl}$ & $\mathrm{Na} / \mathrm{Ca}-\mathrm{SO}_{4}$ & $\mathrm{Ca}-\mathrm{SO}_{4}$ \\
\hline Chlorophyll-a $(\mu \mathrm{g} / \mathrm{l})$ & 2 & 10.5 & 3.7 \\
\hline Trophic state classification ${ }^{a}$ & Oligotrophic & Mesotrophic to eutrophic & $\begin{array}{l}\text { Oligotrophic to } \\
\text { mesotrophic }\end{array}$ \\
\hline Phytoplankton (dominant phylum,gGenus) & Chlorophyta, Ankistrodesmus & $\begin{array}{l}\text { Cryptophyta, Cryptomonas and } \\
\text { Chlorophyta, Ankistrodesmus }\end{array}$ & $\begin{array}{l}\text { Chlorophyta, } \\
\text { Chlorella }\end{array}$ \\
\hline Microbes (dominating phylum; genera) & $\begin{array}{l}\text { Proteobacteria; Acinetobacter, } \\
\text { Synechococcus }\end{array}$ & $\begin{array}{l}\text { Proteobacteria; Hydrogenophaga, } \\
\text { Chlorobaculum, Pseudomonas, Nodularia }\end{array}$ & $\begin{array}{l}\text { Bacteriodetes; } \\
\text { Flavobacterium, Luteolibacter }\end{array}$ \\
\hline Stratification and mixing & $\begin{array}{l}\text { - Strong thermal stratification } \\
\text { (October to March/April) } \\
\text { - Turnover (late autumn/ winter) }\end{array}$ & $\begin{array}{l}\text { - Weak thermal stratification } \\
\text { (October to March/April) } \\
\text { - Turnover (late autumn/ winter) }\end{array}$ & $\begin{array}{l}\text { - Weak thermal stratification } \\
\text { (October toMarch/April) } \\
\text { - Turnover (late autumn/ winter) }\end{array}$ \\
\hline Classification ${ }^{\mathrm{b}}$ & $\begin{array}{l}\text { Slightly alkaline, low TDS Holomictic, } \\
\text { monomictic }\end{array}$ & $\begin{array}{l}\text { Slightly alkaline, high TDS Holomictic, } \\
\text { monomictic }\end{array}$ & $\begin{array}{l}\text { Circum-neutral, low TDS } \\
\text { Holomictic, monomictic }\end{array}$ \\
\hline
\end{tabular}

aTrophic state classification according to de Lange et al. (2018). Only September data for Rooikop and Kleinfontein.

${ }^{\mathrm{b}} \mathrm{Classification}$ of pit lakes according to Eary (1999) and Boehrer and Schultze (2008) 


\section{Are pit lakes an environmentally sustainable closure option for opencast coal mines?}

a total dissolved solids content of $1200 \mathrm{mg} / \mathrm{l}$ and the water is calcium sulphate type.

\section{Are pit lakes an environmentally sustainable closure op- tion for South African coal mines?}

The use of pit lakes in the South African coal mining industry as an environmentally sustainable closure option must consider the following aspects, which should be incorporated into the closure design.

\section{Water balance}

It is critical that the sum of the inflows into the pit lake is less than evaporation to prevent major changes in pit lake water levels. Positive pit lake water balances result in discharge onto surface. Negative water balances result in the pit lake becoming a hydraulic sink. As a result, a carefully designed pit lake where the inflows are equal to or less than the outflows will result in a stable pit lake that will not discharge onto surface. The morphology is a critical factor in determining the environmental sustainability of a pit lake.

\section{Water quality}

The pit lakes studied in this investigation are all alkaline with variable dissolved solids contents and which support phytoplankton, microbes, vegetation, and aquatic life. Although the water quality may not comply with the catchment water quality objectives, the pit lakes are environmentally sustainable. The pit lakes were also seen to support a host of other aquatic life such as birds, fish, amphibians and mammals.

\section{Conclusion}

The surface area of a pit lake is vitally important. A large surface area maximizes evaporation, which directly affects the water balance. In addition, surface runoff should be controlled to avoid excess flow into the pit lake during storm events, which may lead to a temporary positive water balance and uncontrolled discharge into the catchment. Should the pit lake be suitably designed, it forms a water sink and prevents uncontrolled discharge from the mining operations.

The water quality in the pit lakes investigated is alkaline with evaluated dissolved solid content, but is able to support chlorophyll-a, phytoplankton, and microbes. Although the water quality may not comply with catchment water quality standards, it supports a stable ecosystem.

Correctly designed pit lakes are a sustainable closure option for South African coal mines. It is recommended that the current South African legislation be reviewed in order to accommodate pit lakes as a sustainable closure option. However, each pit lake is unique and as a result must be evaluated on a case-by-case basis.

Details of the study can be found in the South African Water Research Commission report TT 797/1/19 (Johnstone, Kennedy, and Mpetle, 2019).

\section{References}

Blanchette, M.L. and Lund, M.A. 2016. Pit lakes are a global legacy of mining: An integrated approach to achieving sustainable ecosystem and value for communities. Science Direct, vol. 23 (December).
Boenrer, B. and Schultze, M. 2008. Stratification of lakes. Reviews of Geophysics, vol. 46, RG2005. doi:10.1029/2006RG000210

CASTENDyK, D.N., EARY, L.E., and Balistrieri, L.A. 2015. Modelling and management of pit lake water chemistry 1. Theory. Applied Geochemistry, vol. 57. pp. 267-288.

CASTENDyK, D.N. and EARY, L.E. 2009. The nature and global distribution of pit lakes. Mine Pit Lakes Characteristics, Predictive Modelling and Sustainability. Society for Mining, Metallurgy and Exploration, Littleton, CO.

Doyle, G.A. and Runnells, D.D. 1997. Physical limnology of existing mine pit lakes. Mining Engineering, vol. 49. pp. 76-80.

De Lange, W.J., Genthe, B., Hill, L., and Oberholser, P.J. 2018. Towards a rapid assessment protocol for identifying pit lakes worthy of restoration. Journal of Environmental Management, vol. 206. pp. 949-961.

EARY, E. 1999. Geochemical and equilibrium trends in mine pit lakes. Applied Geochemistry, vol. 14. pp. 963-987.

Gammons, C.H., Harris, L.N., Castro, J.M., Cott, P.A., and Hanna, B.W. 2009. Creating lakes from open pit mines: Processes and considerations - with emphasis on northern environments. Canadian Technical Report of Fisheries and Aquatic Sciences 2826. https://digitalcommons.mtech.edu/cgi/viewcontent. cgi? article $=1001 \&$ context=geol_engr

HuisAmen, A. and Wolkersdorfer, C. 2015. Modeling the hydrogeochemical evolution of mine water in a decommissioned opencast coal mine. International Journal of Coal Geology, vol. 164. http://dx.doi.org/10.1016/j.coal.2016.05.006

International Council on Mining \& Metals. 2019. Integrated Mine Closure Good Practice Guide. http://www.icmm.com/en-gb/guidance/environmental-stewardship/ integrated-mine-closure-2019

Johnstone, A.C., Kennedy, L., and MpetLe, M. 2019. An investigation to determine if South African coal mine pit lakes are a viable closure option. Water Research Commission publication TT 797/19, volumes $1 \& 2$. Pretoria.

Schultze, M. 2012 The filling and remediation of pit lakes in former open cast lignite mines. PhD thesis, Technical University of Carolo Wilhemina, Braunschweig.

Snyman, C.P. 1998. Coal. The Mineral Resources of South Africa. 6th edn. Wilson, M.G.C. and Anhaeusser, C.R. (eds). Handbook 16, Council for Geoscience, Pretoria.

South Africa. Not dated. The South African National Mine Closure Strategy (in process).

South AfricA. 2015. The Financial Provisioning Regulations, 2015. (Government / notice R1147, Government Gazette 39425, 20 November 2015.

South Africa. 2002. Mineral \& Petroleum Resources Development Act, 28 of 2002 and the Regulations 56(e).

South AfricA. 1998a. National Environmental Management Act, 107 of 1998 and the EIA Regulations. (Government No. 19519, Notice No. 1540. Commencement date: 29 January 1999 [Proc. No. 8, Gazette No. 19703]).

South Africa. 1998b. National Water Act, 36 of 1998.

South AfricA. 1996. Constitution of the Republic of South Africa.

Vandenberg, J., McCullough, C., and CAstendyk, D. 2015. Key issues in mine closure planning related to pit lakes. Proceedings of the 10th International Conference on Acid Rock Drainage and IMWA Annual Conference, Santiago, Chile. https:// www.imwa.info/docs/imwa_2015/IMWA2015_Vandenberg_156.pdf

Wetzel, R.G. 2001. Limnology: Lake and River Ecosystems. 3rd edn. Academic Press, San Diego, CA. 1006 pp. 